\title{
LONGITUDINAL PROCESSES IN SALTO GRANDE RESERVOIR (AMERICANA, SP, BRAZIL) AND ITS INFLUENCE IN THE FORMATION OF COMPARTMENT SYSTEM
}

\author{
ZANATA, L. H. and ESPÍNDOLA, E. L. G. \\ CRHEA, EESC, USP, Av. Trabalhador Sancarlense, no 400, C.P. 292, CEP 13560-970, São Carlos, SP, Brazil \\ Correspondence to: Lucí Helena Zanata, CRHEA, EESC, USP, Av. Trabalhador Sancarlense, no 400, \\ C.P. 292, CEP 13560-970, São Carlos, SP, Brazil, e-mail: lhzanata@ sc.usp.br \\ Received July 6, 2001 - Accepted August 17, 2001 - Distributed May 31, 2002
}

(With 5 figures)

\begin{abstract}
Studies on the longitudinal processes in reservoirs, involving physical, chemical and biological processes have been thoroughly appraised, suggesting the existence of a longitudinal organization controlled by the entrance and circulation of water which inserts modifications in the structuring of the system. To evaluate this effect, the Salto Grande reservoir (Americana, SP) was analyzed in 11 sampling stations in its longitudinal axis, in the rainy and dry seasons of 1997 considering the physical chemical and biological variables. Analyzing the results in agreement with the declining concentration degree of the river-barrage direction, a more significant correlation was verified in the dry period for total phosphorus $\left(r^{2}=0.86\right)$, dissolved total phosphate $\left(r^{2}=0.83\right)$, nitrite $\left(r^{2}=0.93\right)$, inorganic phosphate $\left(r^{2}=\right.$ $0.89)$, ammonium $\left(\mathrm{r}^{2}=0.84\right)$ and suspended material $\left(\mathrm{r}^{2}=0.85\right)$. In the rainy period, only nitrite $\left(\mathrm{r}^{2}=\right.$ $0.90)$ and conductivity $\left(r^{2}=0.89\right)$ presented correlation with the distance of the dam, which demonstrates the effects of precipitation and the operational mechanism of the dam, as well as the distinction among the physical (sedimentation), chemical (oxidation) and biological (decomposition) processes in spatial heterogeneity of the system. These factors were decisive in the organization of these communities, with higher occurrence of rotifers and copepods in relation to cladocerans, the first ones being more abundant in the entrance of the Atibaia river, decreasing towards the dam direction, while copepods presented an inverse pattern. A distribution pattern similar to Copepoda was also verified for the Cladocera, evidencing a tendency to increase the density of organisms in the stations distant to the entrance of the Atibaia river, not being registered, however, a distribution gradient in the longitudinal axis, as observed for rotifers and copepods. In relation to the trophic degree a longitudinal gradient was also verified from eutrophic to oligotrophic depending on the location of the sampling station in relation to the longitudinal axis and period of analysis. The differences obtained, relating to the distribution of the environmental variables, demonstrate a characteristic pattern for reservoirs, with a longitudinal gradient in the sense river-barrage that inserts changes in the physical and chemical composition of the water, contributing to the differentiated establishing of biological communities.
\end{abstract}

Key words: reservoirs, longitudinal gradients, formation of compartment.

\section{RESUMO}

\section{Processos longitudinais no reservatório de Salto Grande (Americana, SP) e sua influência na formação de compartimentos do sistema}

Estudos sobre os processos longitudinais em reservatórios, envolvendo os processos físicos, químicos e biológicos, têm sido amplamente avaliados, sugerindo a existência de uma organização longitudinal controlada pela entrada e circulação da água, a qual insere modificações na estruturação do sistema. Para avaliar esse efeito, o reservatório de Salto Grande (Americana, SP) foi analisado em 11 estações de amostragem de seu eixo longitudinal, nos períodos seco e chuvoso de 1997, considerando-se va- 
riáveis físicas, químicas e biológicas. Analisando-se os resultados de acordo com o grau de decaimento das concentrações no sentido rio-barragem, verificou-se correlação mais significativa no período seco do que no chuvoso para fósforo total $\left(r^{2}=0,86\right)$, fosfato total dissolvido $\left(r^{2}=0,83\right)$, nitrito $\left(r^{2}=0,93\right)$, fosfato inorgânico $\left(r^{2}=0,89\right)$, amônio $\left(r^{2}=0,84\right)$ e material em suspensão $\left(r^{2}=0,85\right)$. No período chuvoso, apenas nitrito $\left(r^{2}=0,90\right)$ e condutividade $\left(r^{2}=0,89\right)$ apresentaram correlação com a distância da barragem, o que demonstra o efeito da precipitação e do mecanismo operacional da barragem, bem como a distinção entre os processos físicos (sedimentação), químicos (oxidação) e biológicos (decomposição) na heterogeneidade espacial do sistema. Esses fatores foram determinantes na organização das comunidades, com maior abundância de rotíferos e copépodos em relação aos cladóceros, sendo os primeiros mais abundantes na entrada do rio Atibaia, decrescendo em direção à barragem, enquanto copépodos apresentaram padrão inverso. Padrão de distribuição semelhante aos copépodos também foi verificado para os cladóceros, evidenciando tendência ao aumento da densidade de organismos nas estações distantes da entrada do rio Atibaia, não sendo registrado, porém, gradiente de distribuição no eixo longitudinal, como observado para rotíferos e copépodos. Em relação ao grau de trofia também se verificou gradiente longitudinal de eutrófico a oligotrófico, dependendo da localização da estação de amostragem em relação ao eixo longitudinal e período analisado. As diferenças obtidas quanto à distribuição das variáveis ambientais demonstram um padrão característico para reservatórios, com gradiente longitudinal no sentido rio-barragem que insere modificações na composição física e química da água, contribuindo para o estabelecimento diferenciado das comunidades biológicas.

Palavras-chave: reservatórios, gradiente longitudinal, formação de compartimentos.

\section{INTRODUCTION}

Artificial reservoirs are distinguished from other natural aquatic ecosystems because of operation mechanisms that alter the conditions of the setting, which together with functions of natural forces, cause the heterogeneous distribution of the organisms in the environment (Tundisi, 1988; Straskraba et al., 1993). In this system, the water time of residence and material contribution input a longitudinal zonation usually associated with the increase of particulate material sedimentation in the river-barrage direction (Thomaz et al., 1997), where each compartment will constitute a section along the longitudinal axis (lotic, transition and lentic) with differentiated characteristics, where the degree of space heterogeneity is influenced by morphometry, flow and stratification conditions, the hydrodynamic conditions are the main causes of the horizontal variability in most of the reservoirs (Straskraba \& Tundisi, 1999).

Studies developed by Armengol et al. (1999) and Zanata (1999) suggest the existence of a longitudinal organization in reservoirs controlled by water circulation, which is related to the physical and chemical characteristics and to the biotic communities of the system. This spatial and temporal heterogeneity in the environmental conditions is a decisive factor in the continuous organization process of the communities in the aquatic envi- ronment (Espíndola, 1994), causing the diversity of habitats, which is considered fundamental for the occurrence of biological diversity (Tundisi et al., 1988).

Considering the importance of water resources, the present study seeks to characterize the physical, chemical and biological processes in the longitudinal axis of the Salto Grande reservoir (Americana, SP), during two seasons of the year (summer and winter), which influence the ecology of the system.

\section{STUDY AREA}

This work was developed in the Salto Grande reservoir, located in the eastern-central area of the State of São Paulo, in the municipal district of Americana, in the coordinates $22^{\circ} 44^{\prime} \mathrm{S}$ and $47^{\circ} 20^{\prime} \mathrm{W}$, at 530 meters of altitude and inserted in the hydrographic basin of the Atibaia river (one of the tributaries of the Piracicaba river, in the headboard area of the upper basin of the Paraná river), which covers an area of $2,724 \mathrm{~km}^{2}$. The reservoir area is $11.5 \mathrm{~km}^{2}$, with a $64 \mathrm{~km}$ perimeter, $17 \mathrm{~km}$ of length, maximum volume of $106 \times 10^{6} \mathrm{~m}^{3}$, maximum depth of $9 \mathrm{~m}$ and a 30-day average water time of residence.

The Atibaia river basin presents high urban and industrial density, mainly in the inferior sector, causing a growing deterioration process of water quality, due mainly to the entrance of domestic and 
industrial effluents from the cities of Paulínia and Campinas. Moreover, it receives significant contribution of organic load from small rivers and streams that receive sanitary sewers without treatment from other cities (Rocha, 1972; Carvalho, 1979; Shimizu, 1981), as well as the material contribution from agricultural activities.

\section{MATERIAL AND METHODS}

To evaluate the longitudinal processes in the reservoir of Salto Grande, 11 collection stations were horizontally distributed in the dam, taking into consideration mainly the longitudinal axis in direction to the entrance of the Atibaia river, main affluent towards the dam. The collecting was carried out on February 14 (higher temperature and higher precipitation) and June 30, 1997 (lower temperature and lower precipitation).

Samples were collected integrating the water column with a suction pump for analysis of physical, chemical and biological parameters, as well as suspended material (Teixeira et al., 1965; Tundisi, 1969), chlorophyll-a (Nusch, 1980) plus total and dissolved nutrients (Golterman et al., 1978; Standard Methods, 1995; Koroleff, 1976; Mackereth et al., 1978), conductivity, temperature and dissolved oxygen analysis were made through a HORIBAU10 field meter, in all the collection stations. Water transparency analysis was accomplished by means of a Secchi disc, through which the limit of the euphotic zone was obtained (Cole, 1975). The obtained results were used for determination of the trophic state of the system in agreement with methodology of Toledo et al. (1983). The samples for analysis of zooplankton (Rotifera, Copepoda and Cladocera) were collected in both periods and in 9 stations with a suction pump and using a plankton net with $30 \mu \mathrm{m}$ of mesh opening. The samples were conditioned in flasks and preserved with formaline $4 \%$ for subsequent analysis in laboratory, specialized methodology and bibliography was used considering the composition and density of the organisms.

\section{RESULTS}

\section{Limnological characteristics of the Salto Grande reservoir}

The results obtained for the limnological variables are presented in Tables 1 and 2; the diffe- rentiation in the water quality in the longitudinal axis of the system was verified, with higher values for some variables in the stations closest to the entrance of the Atibaia river. The conductivity values, for instance, varied from 87 to $238 \mu \mathrm{S} /$ $\mathrm{cm}$ and from 99 to $157 \mu \mathrm{S} / \mathrm{cm}$ in the dry and rainy period, respectively. Significant variation was also obtained for suspended material (from 2.79 to $12.50 \mathrm{mg} / \mathrm{L}$ in the dry period and from 9.33 to $64.9 \mathrm{mg} / \mathrm{L}$ in the rainy period), with higher organic fraction in the dry period (except in stations closer to the Atibaia river) and the inorganic fraction predominating in the rainy period. The higher carriage of aloctone material in the rainy period contributed to the reduction of the euphotic zone limit (from 0.6 to $2.1 \mathrm{~m}$ in the rainy period and from 1.8 to $6.5 \mathrm{~m}$ in the dry period), verifying that in the dry period all the stations presented more than $50 \%$ of the water column with light. The chlorophylla concentration was larger in the rainy period (from 1.95 to $11.86 \mu \mathrm{g} / \mathrm{L}$ ) than in the dry period (from 0.46 to $6.51 \mu \mathrm{g} / \mathrm{L}$ ). For total and dissolved nutrients, in general, a concentration decline in the Atibaia river-barrage direction was verified, mainly in the dry period. The concentrations of total phosphorus varied from 69.58 to $128.85 \mu \mathrm{g} / \mathrm{L}$ in the rainy period and from 39.63 to $244.22 \mu \mathrm{g} / \mathrm{L}$ in the dry period. Among the phosphate compounds, it was only during the rainy period that the total dissolved phosphate and inorganic phosphate did not present a decreasing distribution of concentration. It was also verified for the longitudinal pattern higher concentrations of nitrogen compounds in stations close to the entrance of the Atibaia river and lower concentrations in stations close to the barrage. For nitrite, for instance, a variation was verified from 13.68 to $162.86 \mu \mathrm{g} / \mathrm{L}$ in the rainy period, while that variation occurred from 49.30 to $274.76 \mu \mathrm{g} / \mathrm{L}$ in the dry season (Tables 1 and 2).

\section{Composition and dominance of the zooplanktonic community}

In both analyzed periods, Rotifers and copepods were the most abundant in the Salto Grande reservoir (Tables 3 and 4). In the rainy season the average percentile contribution of Copepoda, Cladocera and Rotifera was of $35.64 \%, 10.93 \%$ and $50.39 \%$ while in the dry period, the variation was of $26.83 \%, 11.25 \%$ and $61.31 \%$, respectively, with differences in the longitudinal axis: Rotifera being the most abundant in stations close to the Atibaia 
river, and Copepoda and Cladocera in stations intermediate and close to the dam.

The Cyclopoida copepods were the most abundant in the reservoir during the two analyzed periods. In the rainy period, this group represented $76.2 \%$ of a total of 898,607 ind. $/ \mathrm{m}^{3}$.

In the dry period, Cyclopoida contributed with $88.2 \%$ of a total of $1,481,051$ ind. $/ \mathrm{m}^{3}$. Calanoida represented $23.8 \%$ and $11.8 \%$ of the copepods found in the rainy and dry periods, respectively. The occurrence of Harpacticoida copepods was only observed in the rainy period, in stations 1 and 2, with 20 ind. $/ \mathrm{m}^{3}$ and station 3, with 75 ind. $/ \mathrm{m}^{3}$ (Table 5).

In the rainy period, rotifers contributed with $50.39 \%$ of the total of individuals. Station 3 pre- sented a larger abundance of organisms (306, 600 ind. $\left./ \mathrm{m}^{3}\right)$, in which was also observed the largest relative abundance of rotifers $(89.90 \%)$, while the smallest contributions occurred in stations 8 , 10 and 11 , where the relative abundance of rotifers varied from $15.79 \%$ to $28.95 \%$. In those stations, the copepods were the dominant organisms (Table 3).

In the dry period, rotifers were more abundant in station 8 , contributing with 831,600 ind. $/ \mathrm{m}^{3}$. The relative abundance of rotifers varied from $86.75 \%$ to $47.24 \%$ in stations 3 and 9 , respectively. In spite of the heterogeneous distribution of the organisms in the system, the rotifers were dominant in all the collected stations during the dry period (Table 4).

TABLE 1

Comparison of limnological data in Salto Grande reservoir in the wet season.

\begin{tabular}{|c|c|c|c|c|c|c|c|c|c|c|c|}
\hline \multirow{2}{*}{ Variable } & \multicolumn{11}{|c|}{ Stations } \\
\hline & 1 & 2 & 3 & 4 & 5 & 6 & 7 & 8 & 9 & 10 & 11 \\
\hline Maximum depth (m) & 4.0 & 2.5 & 1.7 & 5.0 & 10.0 & 3.7 & 5.5 & 7.0 & 2.7 & 13.5 & 19.5 \\
\hline Euphotic limit (m) & 0.6 & 0.9 & 0.9 & 0.9 & 1.5 & 0.9 & 2.1 & 1.8 & 1.9 & 1.5 & 0.6 \\
\hline Conductivity $(\mu \mathrm{S} / \mathrm{cm})$ & 145 & 148 & 157 & 130 & 123 & 117 & 108 & 108 & 105 & 103 & 99 \\
\hline $\begin{array}{l}\text { Total suspended material } \\
(\mathrm{mg} / \mathrm{L})\end{array}$ & 64.90 & 35.85 & 36.87 & 17.01 & 19.04 & 10.72 & 9.33 & 11.71 & 10.78 & 11.83 & 14.40 \\
\hline Organic material $(\mathrm{mg} / \mathrm{L})$ & 22.5 & 13.7 & 10.3 & 5.9 & 5.3 & 3.8 & 3.0 & 3.8 & 4.1 & 4.1 & 3.6 \\
\hline $\begin{array}{l}\text { Inorganic material } \\
(\mathrm{mg} / \mathrm{L})\end{array}$ & 42.4 & 22.2 & 26.6 & 11.1 & 13.8 & 6.9 & 6.3 & 7.9 & 6.7 & 7.7 & 10.8 \\
\hline Chlorophyll-a $(\mu \mathrm{g} / \mathrm{L})$ & 4.88 & 6.28 & 6.98 & 11.86 & 3.49 & 7.67 & 2.23 & 6.98 & 10.46 & 10.46 & 1.95 \\
\hline Total phosphorus $(\mu \mathrm{g} / \mathrm{L})$ & 108.72 & 119.99 & 128.85 & 73.57 & 86.67 & 69.58 & 85.17 & 78.34 & 71.51 & 86.55 & 91.85 \\
\hline $\begin{array}{l}\text { Total dissolved } \\
\text { phosphorus }(\mu \mathrm{g} / \mathrm{L})\end{array}$ & 64.03 & 62.12 & 56.21 & 38.41 & 58.95 & 61.08 & 64.08 & 86.85 & 67.78 & 70.51 & 79.74 \\
\hline $\begin{array}{l}\text { Inorganic phosphate } \\
(\mu \mathrm{g} / \mathrm{L})\end{array}$ & 33.30 & 33.43 & 32.57 & 26.13 & 31.67 & 30.99 & 28.06 & 33.27 & 37.26 & 28.41 & 48.84 \\
\hline $\begin{array}{l}\text { Total organic nitrogen } \\
(\mathrm{mg} / \mathrm{L})\end{array}$ & 3.28 & 6.06 & 6.09 & 2.00 & 1.60 & 2.14 & 1.82 & 1.97 & 1.58 & 1.47 & 2.08 \\
\hline Ammonium $(\mu \mathrm{g} / \mathrm{L})$ & 617.03 & 776.24 & 896.06 & 539.43 & 691.28 & 453.97 & 451.25 & 260.27 & 248.23 & 276.27 & 464.94 \\
\hline Nitrate $(\mu \mathrm{g} / \mathrm{L})$ & $1,020.6$ & $1,066.9$ & $1,060.3$ & $1,009.1$ & 843.6 & 902.9 & 684.0 & 789.8 & 791.7 & 877.7 & 552.8 \\
\hline Nitrite $(\mu \mathrm{g} / \mathrm{L})$ & 155.21 & 162.42 & 162.86 & 118.25 & 88.87 & 76.18 & 26.67 & 20.72 & 27.85 & 22.23 & 13.68 \\
\hline Silicate $(\mathrm{mg} / \mathrm{L})$ & 5.58 & 5.14 & 5.22 & 5.37 & 4.33 & 3.83 & 3.59 & 3.38 & 4.46 & 3.70 & 4.31 \\
\hline
\end{tabular}


TABLE 2

Comparison of limnological data in Salto Grande reservoir in the dry season.

\begin{tabular}{|c|c|c|c|c|c|c|c|c|c|c|c|}
\hline \multirow{2}{*}{ Variable } & \multicolumn{11}{|c|}{ Stations } \\
\hline & 1 & 2 & 3 & 4 & 5 & 6 & 7 & 8 & 9 & 10 & 11 \\
\hline Maximum depth (m) & 3 & 3 & 2 & 7.5 & 11 & 5.7 & 6.5 & 8.5 & 12 & 9 & 7.5 \\
\hline Euphotic limit (m) & 2.4 & 2.4 & 1.8 & 6.3 & 6.3 & 5.7 & 6.5 & 6.3 & 6 & 6 & \\
\hline Conductivity $(\mu \mathrm{S} / \mathrm{cm})$ & 225 & 238 & 219 & 87 & 91 & 154 & 157 & 158 & 163 & 116 & 111 \\
\hline $\begin{array}{l}\text { Total suspended } \\
\text { material (mg/L) }\end{array}$ & 12.50 & 13.75 & 11.62 & 6.74 & 5.05 & 4.83 & 3.47 & 2.79 & 3.29 & 2.99 & 3.30 \\
\hline $\begin{array}{l}\text { Organic material } \\
(\mathrm{mg} / \mathrm{L})\end{array}$ & 6.0 & 6.2 & 4.5 & 3.9 & 2.6 & 2.4 & 2.3 & 2.1 & 1.6 & 2.3 & 1.7 \\
\hline $\begin{array}{l}\text { Inorganic material } \\
(\mathrm{mg} / \mathrm{L})\end{array}$ & 6.5 & 7.6 & 7.1 & 2.9 & 2.5 & 2.5 & 1.2 & 0.7 & 1.7 & 0.7 & 1.6 \\
\hline Chlorophyll-a $(\mu \mathrm{g} / \mathrm{L})$ & 2.32 & 2.79 & 4.18 & 6.04 & 2.79 & 6.04 & 6.51 & 0.46 & 2.32 & 3.72 & 5.11 \\
\hline $\begin{array}{l}\text { Total phosphorus } \\
(\mu \mathrm{g} / \mathrm{L})\end{array}$ & 199.97 & 244.22 & 221.56 & 188.15 & 96.21 & 61.68 & 48.34 & 55.06 & 39.63 & 42.75 & 42.26 \\
\hline $\begin{array}{l}\text { Total dissolved } \\
\text { phosphorus }(\mu \mathrm{g} / \mathrm{L})\end{array}$ & 115.61 & 146.87 & 142.41 & 55.52 & 48.01 & 41.08 & 27.30 & 25.57 & 23.52 & 25.74 & 25.44 \\
\hline $\begin{array}{l}\text { Inorganic phosphate } \\
(\mu \mathrm{g} / \mathrm{L})\end{array}$ & 78.34 & 89.96 & 90.65 & 33.32 & 28.38 & 17.10 & 7.59 & 13.24 & 7.88 & 8.04 & 6.11 \\
\hline $\begin{array}{l}\text { Total organic nitrogen } \\
(\mathrm{mg} / \mathrm{L})\end{array}$ & 1.37 & 1.31 & 1.37 & 0.88 & 0.81 & 1.11 & 0.57 & 2.43 & 1.88 & 1.9 & 1.58 \\
\hline Ammonium $(\mu \mathrm{g} / \mathrm{L})$ & $1,314.5$ & $1,519.9$ & $1,538.5$ & 761.3 & $1,047.1$ & 536.5 & 293.5 & 575.6 & 365.5 & 218.0 & 267.1 \\
\hline Nitrate $(\mu \mathrm{g} / \mathrm{L})$ & $1,944.8$ & $1,932.7$ & $1,591.8$ & $1,464.8$ & $1,304.0$ & $1,483.1$ & $1,377.7$ & $1,325.7$ & $1,368.0$ & $1,404.9$ & $1,335.0$ \\
\hline Nitrite $(\mu \mathrm{g} / \mathrm{L})$ & 274.09 & 274.76 & 235.79 & 160.10 & 137.19 & 115.71 & 65.05 & 98.31 & 64.01 & 49.30 & 51.61 \\
\hline Silicate (mg/L) & 6.87 & 6.26 & 6.88 & 5.95 & 4.90 & 4.71 & 4.93 & 2.34 & 5.06 & 3.47 & 5.00 \\
\hline
\end{tabular}

TABLE 3

Density (ind. $/ \mathrm{m}^{3}$ ) and the relative abundance (\%) of Copepoda, Cladocera, Rotifera and other organisms in the wet season.

\begin{tabular}{|c|c|c|c|c|c|c|c|c|c|}
\hline \multirow{2}{*}{ Stations } & \multicolumn{2}{|c|}{ Copepoda } & \multicolumn{2}{c|}{ Cladocera } & \multicolumn{2}{c|}{ Rotifera } & \multicolumn{2}{c|}{ Other organisms* } & Total \\
\cline { 2 - 10 } & Density & $\%$ & Density & $\%$ & Density & $\%$ & Density & Density \\
\hline 1 & 3,600 & 2.48 & 70 & 0.05 & 115,600 & 79.77 & 25,650 & 17.70 & 144,920 \\
\hline 2 & 5,150 & 2.77 & 120 & 0.06 & 148,800 & 80.09 & 31,710 & 17.07 & 185,780 \\
\hline 3 & 10,125 & 2.97 & 7,885 & 2.31 & 306,600 & 89.90 & 16,445 & 4.82 & 341,055 \\
\hline 5 & 145,578 & 35.87 & 31,455 & 7.75 & 228,480 & 56.30 & 315 & 0.08 & 405,828 \\
\hline 6 & 131,983 & 39.50 & 72,715 & 21.76 & 129,285 & 38.70 & 109 & 0.03 & 334,092 \\
\hline 8 & 150,624 & 54.45 & 51,912 & 18.77 & 74,100 & 26.79 & 0 & & 276,636 \\
\hline 9 & 145,299 & 45.29 & 33,260 & 10.37 & 142,200 & 44.32 & 86 & 0.03 & 320,845 \\
\hline 10 & 191,488 & 56.41 & 47,900 & 14.11 & 98,280 & 28.95 & 1,760 & 0.52 & 339,428 \\
\hline 11 & 114,800 & 66.35 & 30,229 & 17.47 & 27,310 & 15.79 & 672 & 0.39 & 173,011 \\
\hline Total & \multicolumn{2}{|c|}{898,647} & \multicolumn{2}{|c|}{275,546} & $1,270,655$ & & 76,747 \\
\hline$\%$
\end{tabular}

*Insecta larvae, Annelida and Ostracoda. 
TABLE 4

Density (ind. $/ \mathrm{m}^{3}$ ) and the relative abundance $(\%)$ of Copepoda,

Cladocera, Rotifera and other organisms in the dry season.

\begin{tabular}{|c|c|c|c|c|c|c|c|c|c|}
\hline \multirow{2}{*}{ Stations } & \multicolumn{2}{|c|}{ Copepoda } & \multicolumn{2}{|c|}{ Cladocera } & \multicolumn{2}{|c|}{ Rotifera } & \multicolumn{2}{|c|}{ Other organisms* } & \multirow{2}{*}{$\frac{\text { Total }}{\text { Density }}$} \\
\hline & Density & $\%$ & Density & $\%$ & Density & $\%$ & Density & $\%$ & \\
\hline 1 & 4,459 & 6.41 & 2,698 & 3.88 & 56,733 & 81.55 & 5,675 & 8.16 & 69,565 \\
\hline 2 & 1,093 & 1.92 & 20 & 0.04 & 33,893 & 59.47 & 21,987 & 38.58 & 56,993 \\
\hline 3 & 460 & 0.97 & 35 & 0.07 & 40,950 & 86.75 & 5,760 & 12.20 & 47,205 \\
\hline 5 & 138,575 & 17.84 & 70,888 & 9.13 & 567,100 & 73.03 & 0 & & 776,563 \\
\hline 6 & 243,114 & 25.87 & 148,401 & 15.79 & 548,340 & 58.34 & 0 & & 939,855 \\
\hline 8 & 218,055 & 19.09 & 92,721 & 8.12 & 831,600 & 72.80 & 0 & & $1,142,376$ \\
\hline 9 & 250,191 & 32.79 & 152,403 & 19.97 & 360,427 & 47.24 & 0 & & 763,021 \\
\hline 10 & 331,778 & 34.58 & 62,438 & 6.51 & 564,960 & 58.89 & 227 & 0.02 & 959,403 \\
\hline 11 & 293,326 & 38.34 & 91,257 & 11.93 & 380,457 & 49.73 & 78 & 0.01 & 765,118 \\
\hline Total & \multicolumn{2}{|c|}{$1,481,051$} & \multicolumn{2}{|c|}{620,861} & \multicolumn{2}{|c|}{$3,384,460$} & \multicolumn{2}{|c|}{33,727} & \\
\hline$\%$ & \multicolumn{2}{|c|}{26.83} & \multicolumn{2}{|c|}{11.25} & \multicolumn{2}{|c|}{61.31} & \multicolumn{2}{|c|}{0.61} & נעם,טגני \\
\hline
\end{tabular}

* Insecta larvae, Annelida and Ostracoda.

TABLE 5

Comparison of density (ind. $/ \mathrm{m}^{3}$ ) and the relative abundance $(\%)$ of Copepoda (Cyclopoida, Calanoida and Harpacticoida) in the wet and dry season.

\begin{tabular}{|c|c|c|c|c|c|c|c|c|c|c|c|c|}
\hline \multirow{3}{*}{ Stations } & \multicolumn{7}{|c|}{ Wet season } & \multicolumn{5}{|c|}{ Dry season } \\
\hline & \multicolumn{2}{|c|}{ Cyclopoida } & \multicolumn{2}{|c|}{ Calanoida } & \multicolumn{2}{|c|}{ Harpacticoida } & \multirow{2}{*}{ Total } & \multicolumn{2}{|c|}{ Cyclopoida } & \multicolumn{2}{|c|}{ Calanoida } & \multirow{2}{*}{ Total } \\
\hline & Density & $\%$ & Density & $\%$ & Density & $\%$ & & Density & $\%$ & Density & $\%$ & \\
\hline 1 & 3,500 & 95.6 & 140 & 3.8 & 20 & 0.5 & 3,660 & 2,282 & 51.2 & 2,178 & 48.8 & 4,460 \\
\hline 2 & 5,130 & 99.6 & 0 & & 20 & 0.4 & 5,150 & 1,060 & 97.0 & 33 & 3.0 & 1,093 \\
\hline 3 & 10,005 & 98.8 & 45 & 0.4 & 75 & 0.7 & 10,125 & 445 & 96.7 & 15 & 3.3 & 460 \\
\hline 5 & 105,374 & 72.4 & 40,204 & 27.6 & & & 145,578 & 111,485 & 80.5 & 27,090 & 19.5 & 138,575 \\
\hline 6 & 91,434 & 69.3 & 40,549 & 30.7 & & & 131,983 & 198,275 & 81.6 & 44,839 & 18.4 & 243,114 \\
\hline 8 & 93,600 & 62.1 & 57,024 & 37.9 & & & 150,624 & 207,545 & 95.2 & 10,509 & 4.8 & 218,054 \\
\hline 9 & 120,790 & 83.2 & 24,409 & 16.8 & & & 145,199 & 235,043 & 93.9 & 15,148 & 6.1 & 250,191 \\
\hline 10 & 156,904 & 81.9 & 34,584 & 18.1 & & & 191,488 & 283,071 & 85.3 & 48,707 & 14.7 & 331,778 \\
\hline 11 & 97,828 & 85.2 & 16,972 & 14.8 & & & 114,800 & 266,743 & 90.9 & 26,583 & 9.1 & 293,326 \\
\hline Total & \multicolumn{2}{|c|}{684,565} & \multicolumn{2}{|c|}{213,927} & \multicolumn{2}{|l|}{115} & & \multicolumn{2}{|c|}{$1,305,949$} & \multicolumn{2}{|c|}{175,102} & \multirow{2}{*}{$1,481,051$} \\
\hline$\%$ & \multicolumn{2}{|c|}{76.2} & \multicolumn{2}{|c|}{23.8} & \multicolumn{2}{|l|}{0.01} & & \multicolumn{2}{|c|}{88.2} & \multicolumn{2}{|c|}{11.8} & \\
\hline
\end{tabular}

The density of Cladocera varied from 70 ind./ $\mathrm{m}^{3}$ (station 1) to 72,715 ind. $/ \mathrm{m}^{3}$ (station 6), in a total of $275,546 \mathrm{ind} . / \mathrm{m}^{3}$, in the rainy season and of 20 ind. $/ \mathrm{m}^{3}$ (station 2) to 152,403 ind. $/ \mathrm{m}^{3}$ (station $9)$, in a total of 620,861 ind. $/ \mathrm{m}^{3}$, in the dry period, during the two analyzed periods cladocerans were less frequent than copepods and rotifers. Other organisms were found in the analyzed samples, such as larvae insects, annelids and some ostracods, which, in the rainy period and in the dry period (Tables 3 and 4) were more abundant in the stations close to the entrance of the river Atibaia.

In general, the densities were larger in the dry period, when Rotifer $\left(3,384,460\right.$ ind. $\left./ \mathrm{m}^{3}\right)$, Co- 
pepoda $(1,481,051$ ind./m³ $)$, Cladocera $(620,861$ ind.$\left./ \mathrm{m}^{3}\right)$ and other organisms $\left(33,727 \mathrm{ind} . / \mathrm{m}^{3}\right)$ added to a total of $5,520,099$ ind. $/ \mathrm{m}^{3}$, while in the rainy period the density of Rotifer $(1,270,655$ ind./ $\left.\mathrm{m}^{3}\right)$, Copepoda $\left(898,647\right.$ ind. $\left./ \mathrm{m}^{3}\right)$, Cladocera (275,546 ind. $\left./ \mathrm{m}^{3}\right)$ and other organisms (76,747 ind./ $\mathrm{m}^{3}$ ) added to $2,521,595$ ind. $/ \mathrm{m}^{3}$ (Tables 3 and 4 ).

\section{DISCUSSION}

Spatial and temporal characterization of the environmental variables in the Salto Grande reservoir

The distribution of all the presented environmental variables demonstrates a characteristic pattern for reservoirs, as thoroughly discussed by Armengol et al. (1999). According to these authors, nutrients can be diluted by water, resulting in the establishment of a longitudinal gradient in the composition of the water of a reservoir, which contributes to the qualitative and quantitative differentiated establishment of the biological communities.

As mentioned previously, in the Salto Grande reservoir an accentuated longitudinal gradient of distribution of some variables was verified, demonstrating the heterogeneity of the system and the variation of the conditions of the reservoir, in both study periods. To evaluate the variation and the decline degree in relation to the chemical composition of the water, an analysis similar to that developed by Armengol et al. (1999) was made, in which the author calculates the existent correlation between a certain variable and the distance of the barrage. The obtained results are presented in Fig. 1, verifying a more significant correlation in the dry than in the rainy period for total match $\left(r^{2}=0.86\right)$, dissolved total phosphate $\left(r^{2}=0.83\right)$, nitrite $\left(r^{2}=0.93\right)$, inorganic phosphate $\left(r^{2}=0.89\right)$, ammonium $\left(r^{2}=0.84\right)$ and suspended material $\left(r^{2}=\right.$ $0.85)$. In the rainy period, only nitrite $\left(r^{2}=0.90\right)$ and conductivity $\left(\mathrm{r}^{2}=0.89\right)$ presented correlation with the distance of the barrage, which clearly demonstrates the outstanding effect of the precipitation and of the operational mechanism of the barrage in the space heterogeneity of the system.

As also presented by Armengol et al. (1999), it is possible, through the comparison of the exponents of the declining equation, to measure the efficiency of the processes involved in the reduction of the concentration of variables analyzed along the Salto Grande reservoir (Fig. 2). As shown in
Fig. 2, small variations occurred in conductivity (0.05 - rainy and dry period), demonstrating similarity with the results obtained by Armengol et al. (1999) in the Sau reservoir (Spain), this fact being attributed to the dilution by small tributaries, morphology of the basin or precipitation. Other components showed high rates of decrease in the longitudinal axis, such as suspended material (0.160.17 - rainy and dry period, respectively), probably due to the sedimentation process, already observed by Leite (1998) for that system. The results obtained for ammonium ion $(0.10-0.20$, in the rainy and dry periods, respectively) and phosphate compounds (0.20-0.30, in the dry period) were similar to those observed by Armengol et al. (1999), this being attributed to the precipitation that can happen to phosphate compounds and the chemical transformation, such as the case of ammonium nitrification, processes in which the activity of organisms is essential.

Through the calculation of the variation rate (Fig. 1) and of the analysis of the decline equation (Fig. 2) it is possible to verify if processes are of biological origin or not, evidenced by the role of the sedimentation, chemical transformation, precipitation and biological activity, although, for the most part, a combination of morphologic, climatological and trophic degree factors occurred, which serve as support so that other processes can take place in the system.

In the case of the Salto Grande reservoir, the depositional process is important for the improvement of the water quality, making it function as a sedimentation basin or play the part of a tertiary treatment in response to the entrance of polluted water from the Atibaia river. However, biological activities related to production and decomposition are also important for the establishment of a gradient in the reservoir, once the communities are organized in relation to a trophic gradient.

The Salto Grande reservoir is in advanced eutrophication process due to the constant discharge of industrial and domestic effluents that arrive to the system through punctual and diffuse sources.

In the rainy period, the material contribution for the reservoir is larger due to the high pluviometric indexes. Besides the carrying of aloctone material that enriches the system, it should also be considered a possible liberation of nutrients of the sediment through the removal of the water flow and by biological and chemical processes (Lijklema, 1994). 
Wet season

Distance at the dam $(\mathrm{km})$
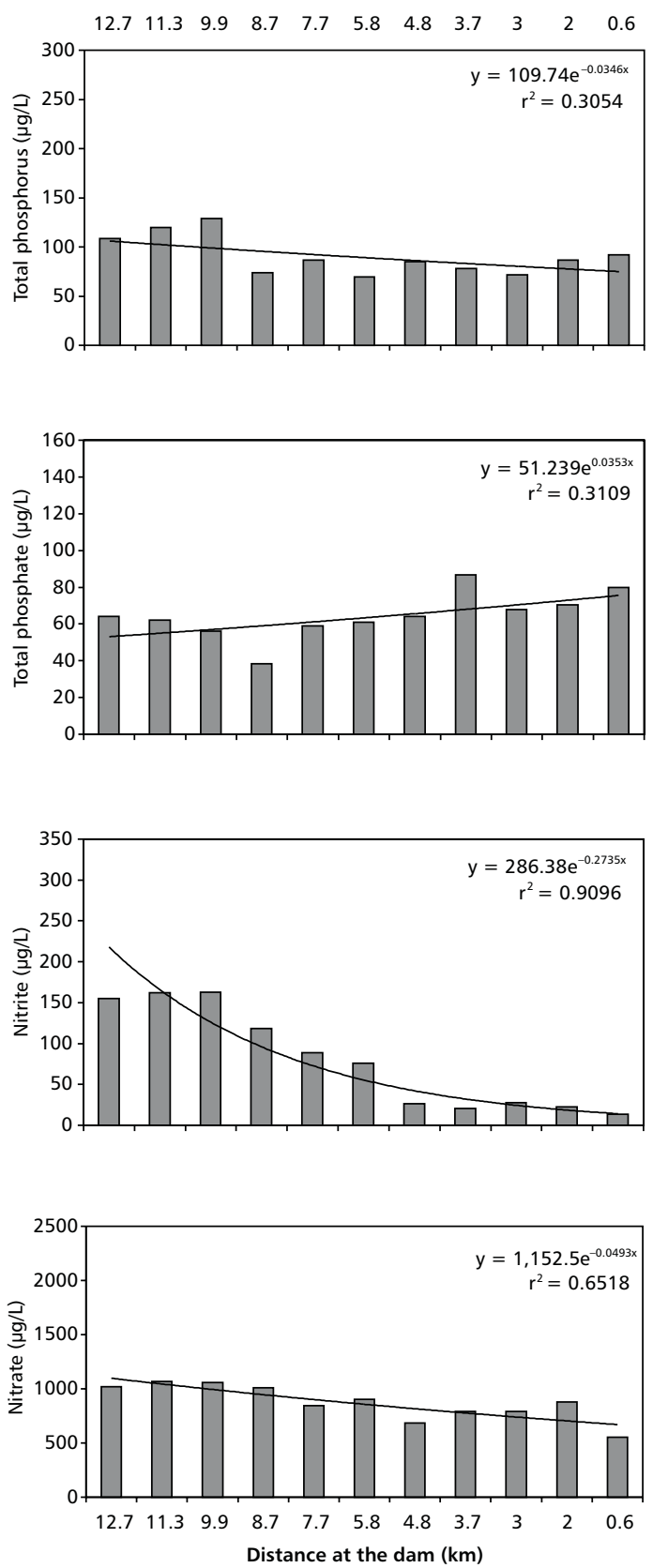

$\square$ Concentration - Decay exponencial
Dry season
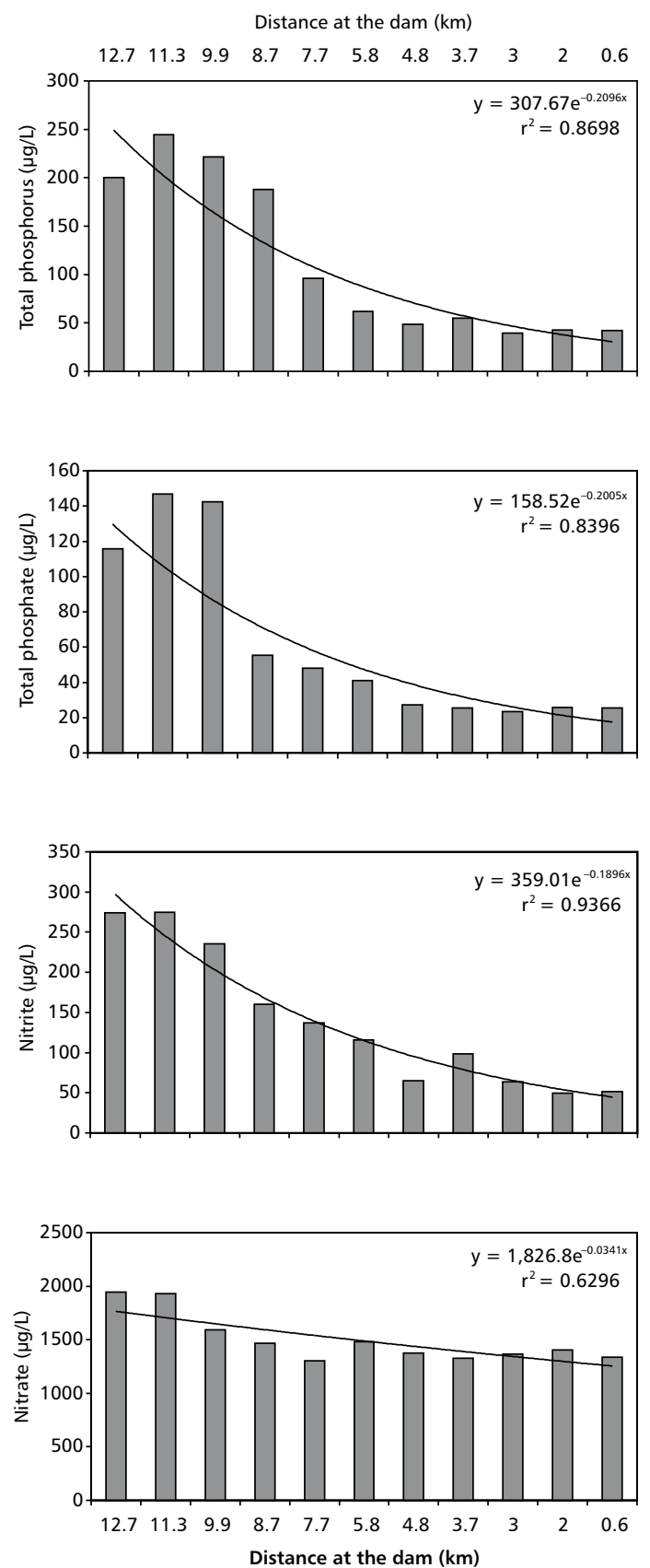

$\square$ Concentration —- Decay exponencial

Fig. 1 - Evolution of the chemical, physical and biological variables in the Salto Grande reservoir from the Atibaia river to the dam. The equations are relating of each variable with the distance at the dam. 
Wet season

Distance at the dam $(\mathrm{km})$
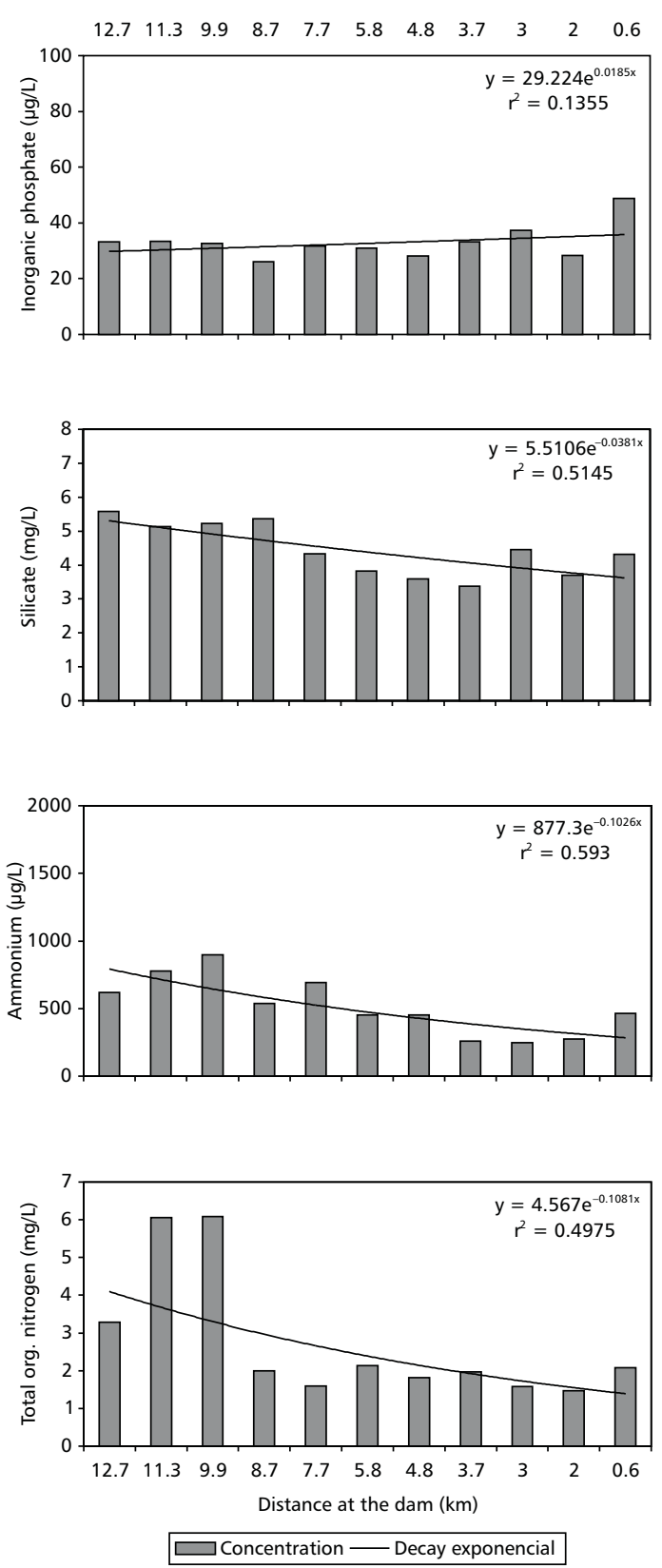

Fig. $1-($ Continued $)$.
Dry season

Distance at the dam $(\mathrm{km})$
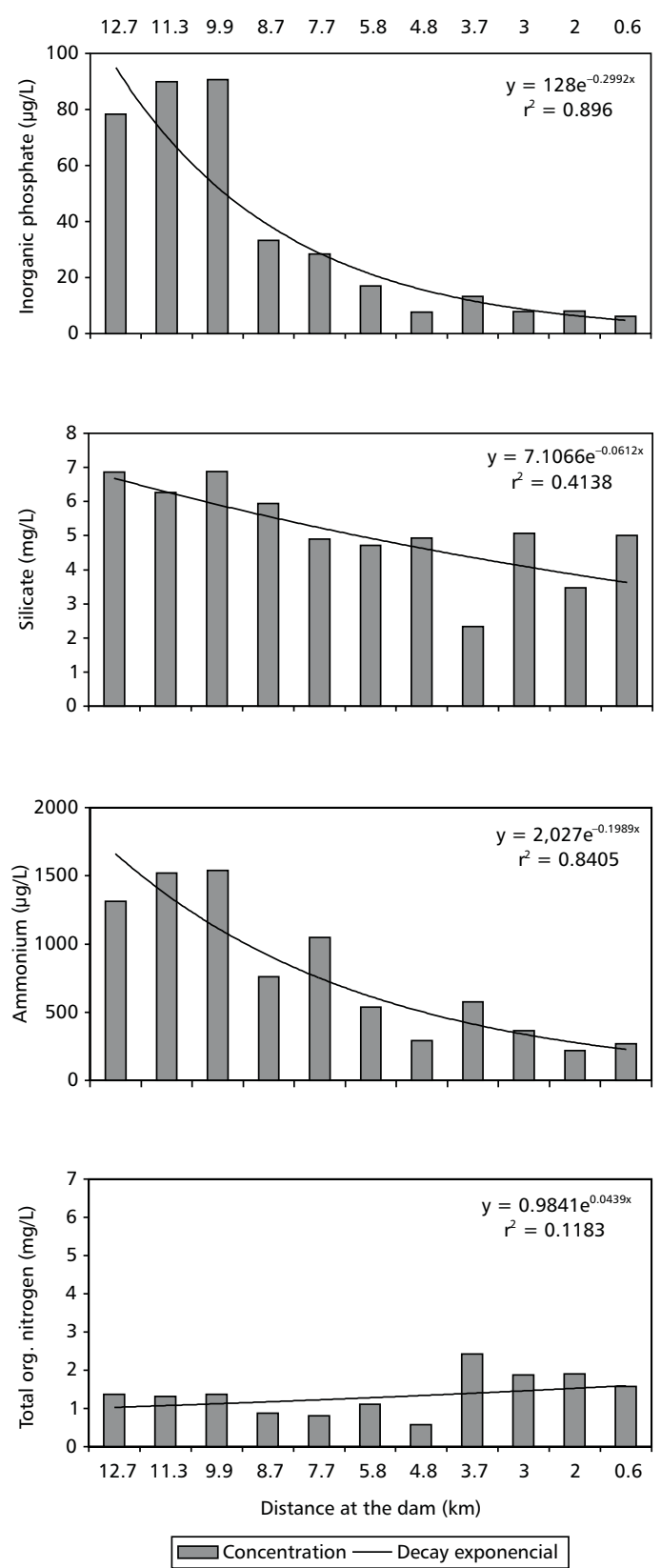
Wet season

Distance at the dam $(\mathrm{km})$
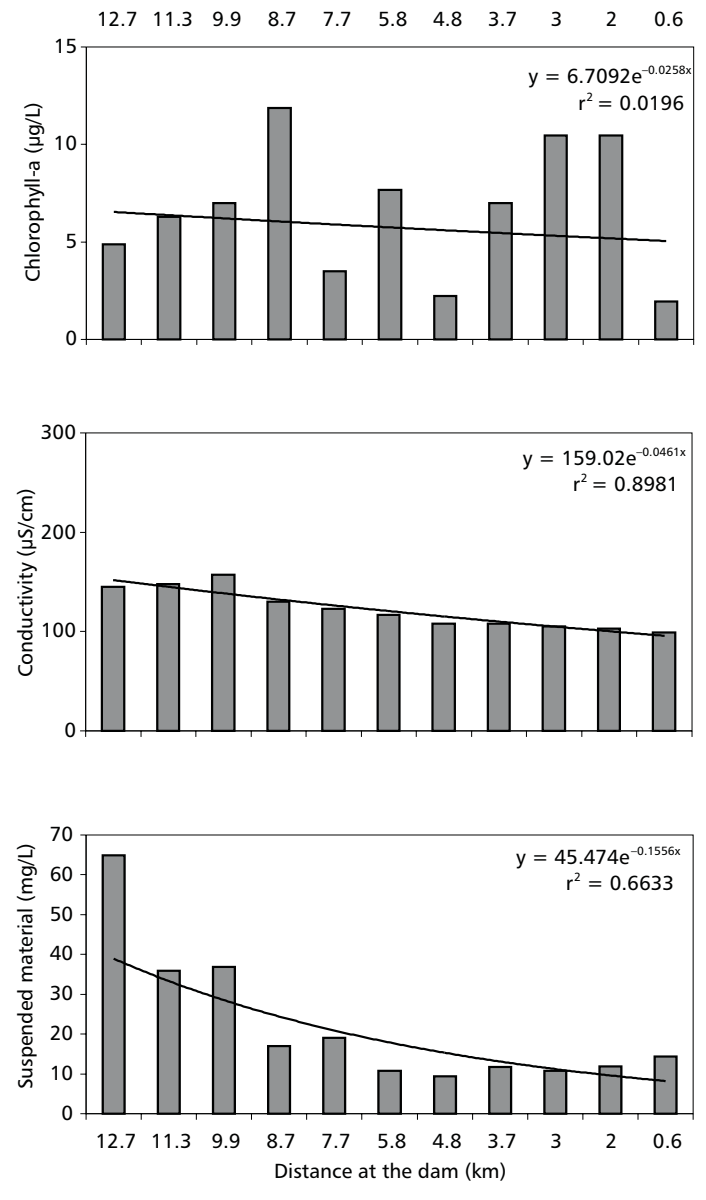

$\square$ Concentration - Decay exponencial
Dry season

Distance at the dam $(\mathrm{km})$
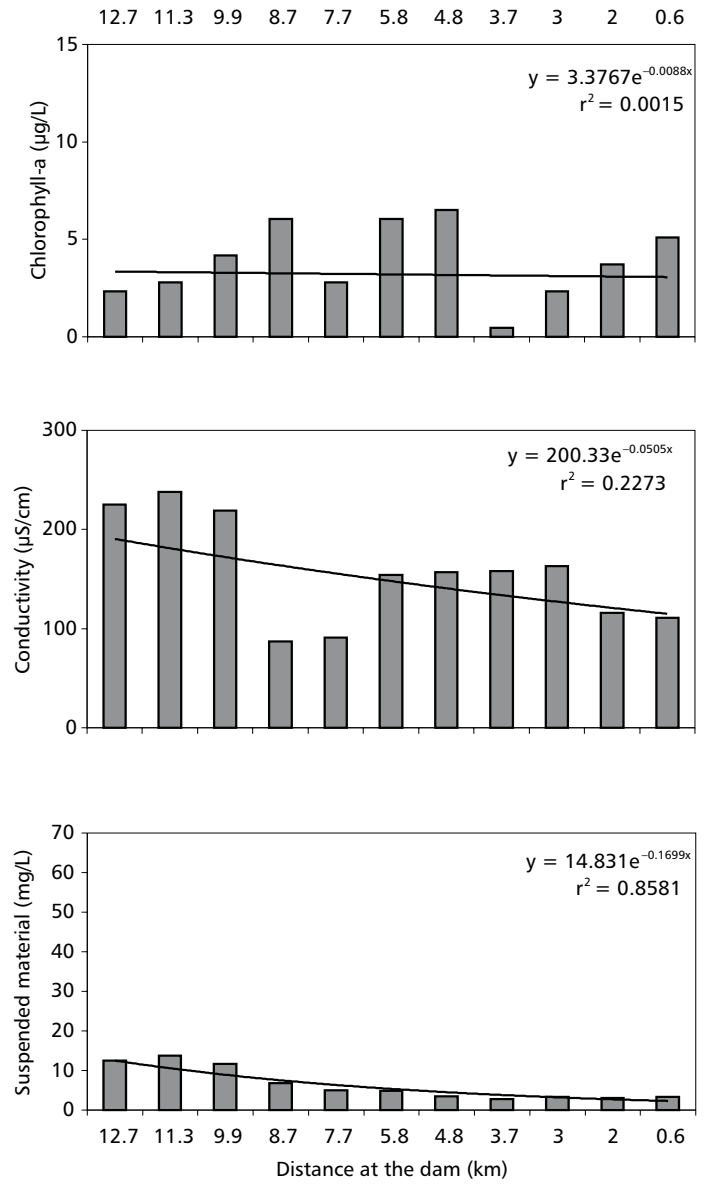

$\square$ Concentration - Decay exponencial

Fig. $1-($ Continued $)$.

In the dry period, the lowest water flow and larger residence time (caused by low indexes of pluviosity), as well as the morphometry of the system, favored the sedimentation of the aloctone material that arrived mainly through the Atibaia river.

That process might have caused a longitudinal gradient in the reservoir, leading to a more eutrophic condition in areas close to the entrance of the Atibaia river to a less eutrophic condition close the barrage (Fig. 3).

Considering all the obtained information, it is verified that the Salto Grande reservoir is a highly impacted system by the punctual and diffuse entrances of nutrients, sediment and metals (as presented by Tonissi, 1999), which present close relationship with functions of climatological forces (mainly precipitation) and antropogenics (use and occupation of the hydrographic basin and operational mechanisms of the barrage). Given the constant entrance of aloctone material and its effects in the physical, chemical and biological characteristics, the system is considered eutrophic with tendencies to mesotrophic and oligotrophic, depending on the location of the sampling stations in relation to the longitudinal axis and season (Fig. 3). 

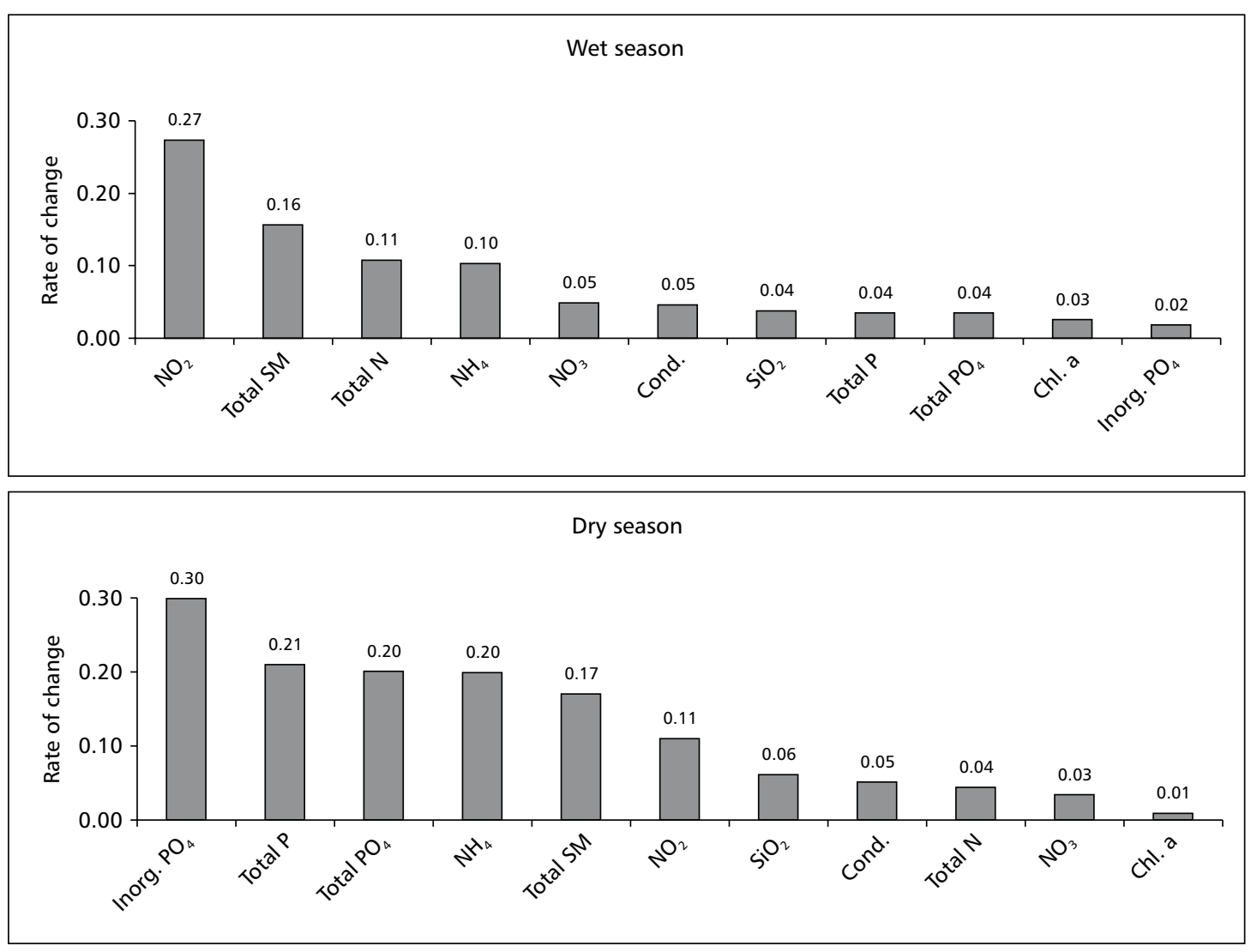

Fig. 2 - Measure of the efficiency of the processes involved in the reduction of the concentrations of the variables analyzed in the Salto Grande reservoir.

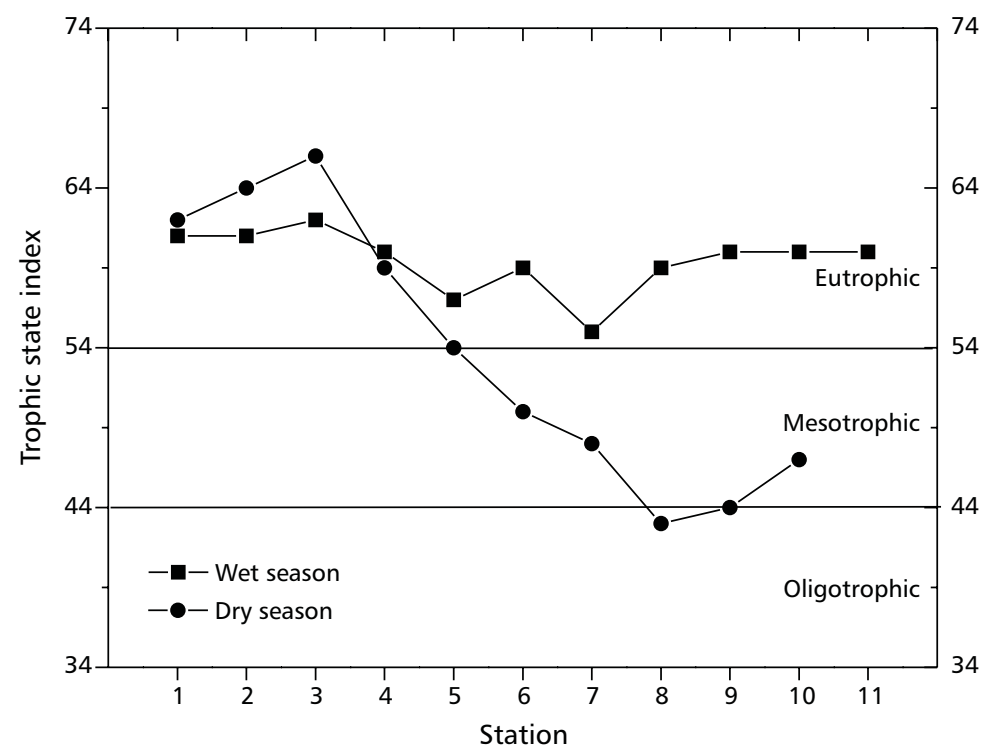

Fig. 3 - Trophic state index in the Salto Grande reservoir. 


\section{Space and temporal heterogeneity of the zooplanktonic community}

In the Salto Grande reservoir, the heterogeneity did not only occur in the distribution, but also in the composition and density of organisms of the zooplanktonic community while comparing the analyzed periods. It can be observed that the physical, chemical and biological characteristics of the reservoir favored a larger abundance of Rotifer and Copepoda.

In the rainy period, in spite of the density of those organisms being similar, considering the longitudinal axis of the system, its spatial distribution was differentiated. Rotifers were more abundant in the entrance of the Atibaia river, presenting a decreasing gradient in direction to the barrage, while, in relation to copepods, an inverse distribution was verified, being these organisms more abundant in the stations distant to the river entrance (Fig. 4).
A dominance of rotifers took place during the dry period in the reservoir in relation to the density of organisms and copepod was the second most abundant group. In general, the density of organisms was larger in that period, but the distribution was similar to that observed in the rainy period. In relation to the cladocerans, the distribution pattern observed evidenced a tendency to the increase of organism density in the stations distant to the entrance of the Atibaia river. However, a distribution gradient was not registered in the longitudinal axis, as observed for rotifers and copepods. Other analyzed organisms (such as Dipteran larvae, annelids and ostracods) were more abundant in stations close to the entrance of the Atibaia river in the two analyzed periods, with inferior density for the other groups. The distribution of Rotifer, Copepoda and Cladocera in the located stations in the longitudinal axis of the reservoir can be observed in Fig. 4.
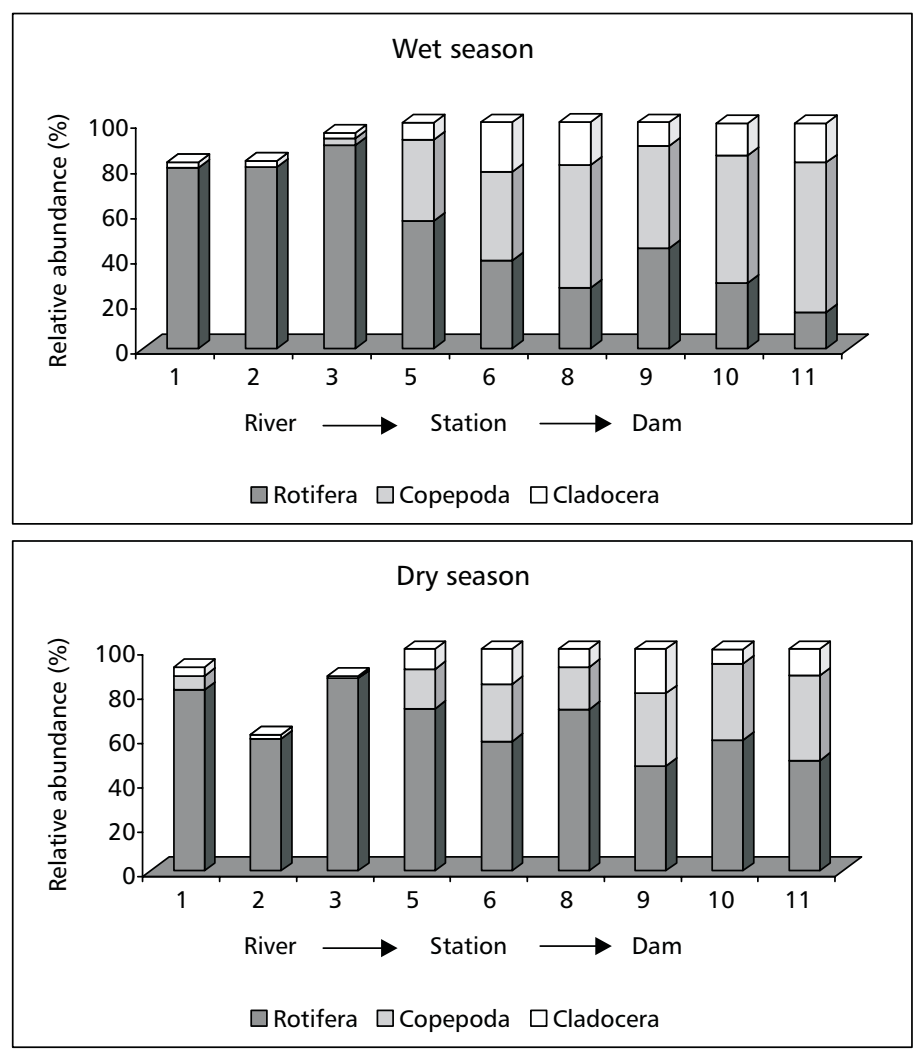

Fig. 4 - Longitudinal distribution of the relative abundance of zooplankton community in the Salto Grande reservoir 
In relationship to rotifers, the literature has demonstrated that its dominance is associated to the increase of the trophic degree (Esteves \& Sendacz, 1988), which is related to the feeding habits of this group, which include the ingestion of small particles such as bacteria and organic debris, usually abundant in eutrophic systems (Nogueira, 1996). In that way rotifer distribution in the Salto Grande reservoir might have been influenced by the suspension material concentration that also presented a decreasing gradient in the entrance of the reservoir in barrage direction. That sedimentation was directly related with the morphometry of the system (Leite, 1998).

However, the temporal variation in the density of the organisms was also sure for the operational regime of the reservoir. The smallest densities for rotifers were verified in the rainy season, in which the reservoir presents smaller time of residence of water. According to Rocha et al. (1999), organisms such as rotifers, protozoans and nauplii copepods are more susceptible to the intense flow due to their size and location in the water column.

The inverse distribution of copepods in relation to the rotifers possibly occurred as a function of food supply. Besides its distribution, the composition of this group can also be related to feeding habits. In the Salto Grande reservoir the dominance of Cyclopoida in relation to Calanoida took place during the rainy and dry period. In general, the distribution of copepods in the longitudinal axis of the Salto Grande reservoir evidenced a better adaptation of the organisms in the stations distant to the entrance of the Atibaia river (Fig. 4). However, considering the horizontal distribution of Cyclopoida and Calanoida (Fig. 5) in the rainy period, a better adaptation tendency of Calanoida was observed in the stations distant to the entrance of the river Atibaia, while Cyclopoida was present in the whole reservoir, with superior density. In the dry period the dominance of Cyclopoida among the copepods was evident, however its distribution didn't present a defined pattern (Fig. 5).
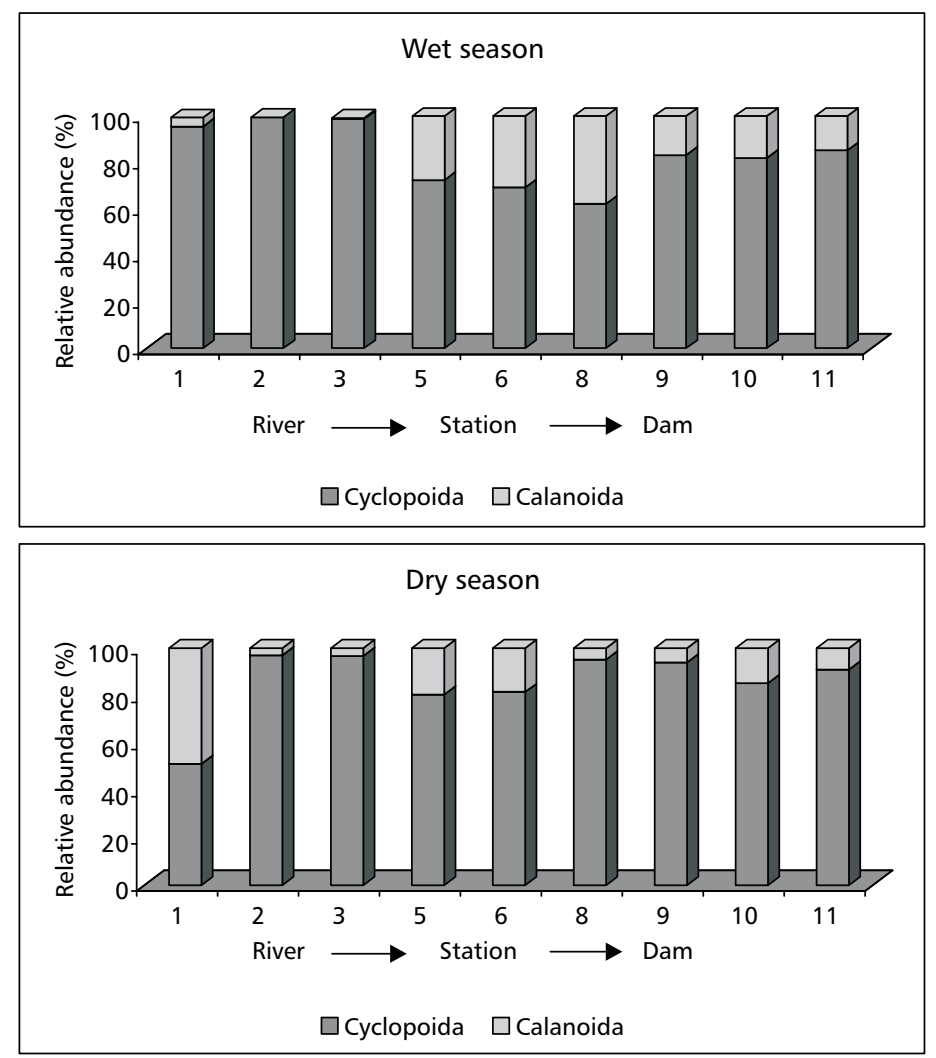

Fig. 5 - Longitudinal distribution of the relative abundance between Cyclopoida and Calanoida in the Salto Grande reservoir. 
The density of organisms was also related with the water retention time in the reservoir. As for Copepoda, Rotifera and Cladocera, the density of organisms was directly proportional to the time of retention, in other words, the larger the time of retention the higher the density of organisms. As discussed above, the communities are sensitive to the operational regime, mainly the smallest ones, such as rotifers (Rocha et al., 1999). In that way, it is possible that the numeric likeness between rotifers and copepods in the rainy period has occurred due to the effect of the intense water flow being more negative on rotifers than on copepods. In the dry period, when the time of retention was larger, the dominance of rotifers on other groups was more evident.

In relation to the cladocerans, it was observed that this group did not numerically dominate the zooplanktonic community in any of the stations during the studied periods and they were better adapted in the stations distant to the entrance of the Atibaia river, where the characteristics of the system are more similar to a lake.

Acknowledgments - The authors wish to express their appreciation for the financial support of the Brazilian research institutions, FAPESP and CAPES, as well as the PPG-SEA/ EESC-USP.

\section{REFERENCES}

ARMENGOL, J., GARCIA, J. C., COMERMA, M., ROMERO, M., DOLZ, J., ROURA, M., HAN, B. H., VIDAL, A. \& SIMEK, K., 1999, Longitudinal processes in canyon type reservoir: the case of Sau (N.E. SPAIN), pp. 313-345. In: J. G. Tundisi \& M. Straškraba (eds.), Theoretical reservoir ecology and its applications. Brazilian Academy of Sciences and Backhuys Publishers, 585p.

CARVAlHO, M. A. J., 1979, A Represa de Americana, São Paulo: aspectos físico-químicos e variação das populações de Copepoda Cyclopoida de vida livre. Tese de Doutorado, Instituto Biológico, Universidade de São Paulo, São Paulo, 148p.

COLE, G. A., 1975, Textbook of limnology. Mosby Company, St. Louis, $427 \mathrm{p}$.

ESPÍNDOLA, E. L. G., 1994, Dinâmica da associação congenérica das espécies de Notodiaptomus (Copepoda, Calanoida) no reservatório de Barra Bonita (SP). Tese de Doutorado, Escola de Engenharia de São Carlos, Universidade de São Paulo, São Carlos, 363p.

ESTEVES, K. E. \& SENDACZ, S., 1988, Relações entre a biomassa do zooplâncton e o estado trófico de reservatórios do Estado de São Paulo. Acta Limnol. Brasil., 2: 587-604.
GOLTERMAN, H. L., CLYMO, R. S. \& OHNSTAD, M. A. M., 1978, Methods for physical and chemical analysis of freshwaters. $2^{\text {nd }}$ ed., Blackwell Scientific, IBP Handbook, London, 213p.

KOROLEFF, F., 1976, Determination of nutrients, pp. 117181. In: K. Ggrasshoff (ed.), Methods of seawater analisys. Verlag. Chemie. Weinhein, 317p.

LEITE, M. A., 1998, Variação espacial e temporal da taxa de sedimentação no reservatório de Salto Grande (Americana, SP) e sua influência sobre as características limnológicas do sistema. Dissertação de Mestrado, Escola de Engenharia de São Carlos, Universidade de São Paulo, São Carlos, 170p.

LIJKLEMA, L., 1994, Nutrient dynamics in shallow lakes: effects of changes in loading and role of sediment-water interactions. Hydrobiologia, 275/276: 335-348.

MACKERETH, F. J. H., HERON, J. \& TALLING, J. F., 1978, Water analysis: some revised methods for limnologists. (Freshwater Biological Association Scientific Publication, 36), Titus Wilson \& Sons Ltda, Kendal, 117p.

NOGUEIRA, M. G., 1996, Comparação, abundância e distribuição espaço-temporal das populações planctônicas e das variáveis físico-químicas na represa de Jurumirim, Rio Paranapanema, SP. Tese de Doutorado, Escola de Engenharia de São Carlos, Universidade de São Paulo, São Carlos, 439p.

NUSCH, E. A., 1980, Comparison of different methods for Chlorophyll and phaeopigments determination. Arch. Fur Hydrobiol., 14: 14-36.

ROCHA, A. A., 1972, Estudo sobre a fauna bentônica da Represa de Americana no Estado de São Paulo. Dissertação de Mestrado, Universidade de São Paulo, São Paulo, 65p.

ROCHA, O., MATSUMURA-TUNDISI, T., ESPÍNDOLA, E. L. G., ROCHE, K. F. \& RIETZLER, A. C., 1999, Ecological theory applied to reservoir zooplankton, pp. 457-476. In: J. G. Tundisi \& M. Straškraba (ed.), Theoretical reservoir ecology and its applications. Brazilian Academy of Sciences and Backhuys Publishers, 585p.

SHIMIZU, G. Y., 1981, Represa de Americana: um estudo de distribuição batimétrica da fauna bentônica. Tese de Doutorado, Instituto de Biociências, Universidade de São Paulo, São Paulo, 148p.

STANDARD METHODS, 1995, For examination of water and wastwater. In: A. D. Eaton et al. (eds.), $19^{\text {th }}$ ed. American Public Health Association, Washington, 1268p.

STRAŠKRABA, M. \& TUNDISI, J. G., 1999, Reservoir water quality management. In: Guidelines of lake management. International Lake Environment Committee, 229p.

STRAŠKRABA, M., TUNDISI, J. G. \& DUNCAN, A., 1993, Introduction, pp.7-9. In: M. Straškraba, J. G. Tundisi \& A. Duncan (eds.), Comparative reservoir limnology and water quality management. Kluwer Academic Publishers, Dordrecht, 291p.

TEIXEIRA, C., TUNDISI, J. G. \& KUTTNER, M. B., 1965, Plankton studies in a mangrove. II. The standing-stock and some ecological factors. Bol. Inst. Oceanogr., 24: 23-41. 
TOLEDO, A. P., TALARICO, M., CHINEZ, S. J. \& AGUDO, E. G., 1983, A aplicação de modelos simplificados para a avaliação do processo da eutrofização em lagos e reservatórios tropicais. In: $12^{\circ}$ Congresso Brasileiro de Engenharia Sanitária e Ambiental. Anais, Camboriú, SC.

THOMAZ, S. M., BINI, L. M. \& ALBERTE, S. M., 1997, Limnologia do reservatório de Segredo: padrões de variação espacial e temporal, pp. 19-37. In: A. A. Agostinho \& L. C. Gomes (eds.), Reservatório de Segredo: bases ecológicas para o manejo. Editora da Universidade Estadual de Maringá, Maringá, 387p.

TONISSI, F. B., 1999, Avaliação ecotoxicológica do reservatório de Salto Grande, Americana (SP), como subsídio para a análise da qualidade ambiental do sistema. Dissertação de Mestrado, Escola de Engenharia de São Carlos, Universidade de São Paulo, São Carlos, 130p.

TUNDISI, J. G., 1969, Produção primária, "standing-stock" e fracionamento do fitoplâncton na região lagunar de Cananéia. São Paulo, Tese de Doutorado, Universidade de São Paulo, 131p.
TUNDISI, J. G., 1988, Impactos ecológicos da construção de represa: aspectos específicos e problemas de manejo, pp. 1-76. In: J. G. Tundisi (ed.), Limnologia e manejo de represas. Série Monografias em Limnologia, 1ํovol., Tomo 1, 506p.

TUNDISI, J. G., MATSUMURA-TUNDISI, T., HENRY, R., ROCHA, O. \& HINO, K., 1988, Comparação do estado trófico de 23 reservatórios do Estado de São Paulo: Eutrofização e manejo, pp. 165-204. In: J. G. Tundisi (ed.), Limnologia e manejo de represas. Série Monografias em Limnologia, 1o vol., Tomo 1, 506p.

ZANATA, L. H., 1999, Heterogeneidade ambiental do reservatório de Salto Grande (Americana/SP) com ênfase na distribuição das populações de Cladocera. Dissertação de Mestrado, Escola de Engenharia de São Carlos, Universidade de São Paulo, São Carlos, 218p. 